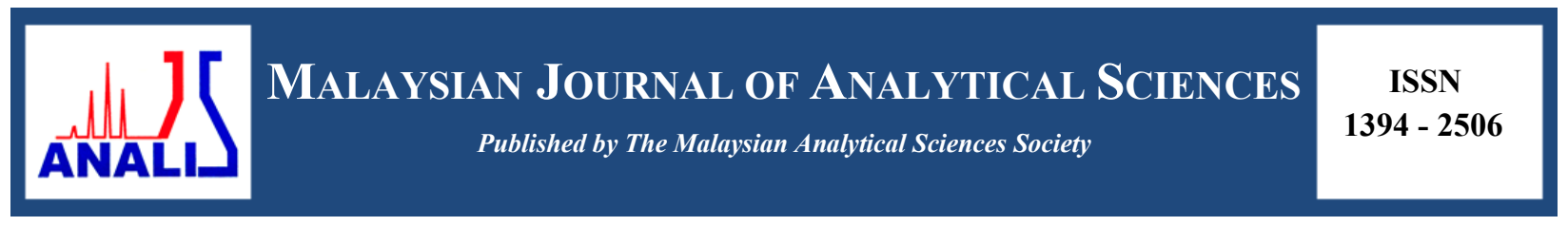

\title{
PERCENTAGE DIFFERENCE OF RESISTIVITY OF NANOPARTICLES IN DETERMINING CRUDE OIL USING SAND-PACK EXPERIMENTAL METHOD
}

\author{
(Peratusan Perbezaan Kerintangan Nanopartikel Dalam Penentuan Minyak Mentah Mengunakan \\ Kaedah Ujikaji Pek Pasir)
}

\author{
Mohd Zulkifli Mohamad Noor ${ }^{1 *}$, Mariyamni Awang ${ }^{2}$, Sonny Irawan ${ }^{2}$ \\ ${ }^{I}$ Faculty of Chemical Engineering \& Natural Resources, \\ Universiti Malaysia Pahang, 26300 Gambang, Pahang, Malaysia \\ ${ }^{2}$ Department of Petroleum Engineering,
}

Universiti Teknologi PETRONAS, 32610 Bandar Seri Iskandar, Perak, Malaysia

*Corresponding author: mzulkifli@ump.edu.my

Received: 28 November 2016; Accepted: 5 February 2017

\begin{abstract}
Nanoparticle with its nanoscale can be used as a data collector in every part of the development of the petroleum field. By having a hydrophilic condition for the nanoparticles, it can move to the targeted area in the water zone. The hydrophilic condition will differentiate between oil zone and water zone. The objective of the study is to use the hydrophilic nanoparticles to detect the oil and water zones using sand-pack displacement test. An experiment using the sand-pack method was done to show that the hydrophilic nanoparticles can be used to collect data. The nanoparticles used were aluminum oxide $\left(\mathrm{Al}_{2} \mathrm{O}_{3}\right)$ and nickel zinc ferrite oxide $(\mathrm{NiZnFeO})$. The results showed that for $\mathrm{NiZnFeO}$, at 3-inch distance from the injection point, the percentage difference increased from $15 \%$ to $25 \%$, while for $\mathrm{Al}_{2} \mathrm{O}_{3}$, the nanoparticles also showed the same increment but different in values, which were from $6 \%$ to $15 \%$. This is shown by the significant change of resistivity percentage at the 3 -inch distance. To conclude, the use of both types of nanoparticles that have hydrophilic nanoparticles can show the significant changes for resistivity at internal short front face of well reservoir with oil zone only.
\end{abstract}

Keywords: nanoparticles, formation characterization, sand-pack displacement, resistivity

\begin{abstract}
Abstrak
Nanopartikel dengan skala nano boleh digunakan sebagai pengumpul data di setiap bahagian pembangunan bidang petroleum. Dengan adanya keadaan hidrofilik untuk nanopartikel, ia boleh bergerak ke kawasan yang disasarkan di zon air. Keadaan hidrofilik akan membezakan antara zon minyak dan zon air. Objektif kajian ini adalah untuk menggunakan nanopartikel hidrofilik untuk mengesan zon minyak dan air menggunakan ujian pek pasir. Satu eksperimen menggunakan kaedah pek pasir dilakukan untuk menunjukkan bahawa nanopartikel hidrofilik boleh digunakan dalam mengumpul data. Nanopartikel yang digunakan adalah aluminium oksida $\left(\mathrm{Al}_{2} \mathrm{O}_{3}\right)$ dan nikel zink ferit oksida (NiZnFeO). Hasil kajian menunjukkan bahawa untuk $\mathrm{NiZnFeO}$, pada jarak 3 inci dari sudut suntikan, perbezaan peratusan meningkat daripada $15 \%$ kepada $25 \%$, manakala bagi $\mathrm{Al}_{2} \mathrm{O}_{3}$, nanopartikel juga menunjukkan kenaikan yang sama tetapi berbeza dalam nilai iaitu dari $6 \%$ kepada $15 \%$. Ini ditunjukkan oleh perubahan yang ketara peratusan kerintangan pada jarak 3 inci. Kesimpulannya, penggunaan kedua-dua jenis nanopartikel yang mempunyai nanopartikel hidrofilik boleh menunjukkan perubahan signifikan bagi kerintangan muka depan pendek dalaman takungan baik dengan zon minyak sahaja.
\end{abstract}

Kata kunci: nanopartikel, penentuan formasi, pengaliran pek pasir, kerintangan 


\section{Introduction}

In the oil and gas industry, nanotechnology has been applied for approximately more than 50 years in many branches like exploration, drilling, production, Enhanced Oil Recovery (EOR), as well as refining and processing [1]. There are many tools used in well logging and one of the most important logging tools is resistivity logging. Resistivity logging has been widely used in well logging. It is one of the useful induction logging combination tools that have been enhanced by replacing the short normal quantitative interpretation [2]. It is also known as electric logging tool. The resistivity logging consists of two types of logging systems, which are dual lateral log and induction log. At present, resistivity logging uses both types of logs but the most commonly used logging is the induction logging. Besides that, the dual lateral log is used as a combination with the induction log for resistivity logging. Therefore, the quality of resistivity measurements is increased for the logging [3].

Research that focuses on nanoparticles used in well logging has not been attempted so far. Nevertheless, excellent works have been carried out on the Enhanced Oil Recovery (EOR). The nanoparticles are used to increase oil recovery via the EOR method [4]. Injected nanoparticles in the formation will somehow push the leftover oil in the formation to the wellbore for recovery and it has been proven in some recent studies. The idea is by mixing the nanoparticles with water and they will increase the electrical properties of the water. Furthermore, it is known that metal oxide nanoparticles do have good electrical properties that can change the electrical properties of the water. Therefore, the resistivity of water is altered by adding nanoparticles into it. Hence, the motivation for the use of nanoparticles in well logging becomes a more interesting study to be conducted. The low resistivity condition for oil and brine water can be solved by conducting the current research.

The conditions of low resistivity and low contrast pay on the resistivity are also termed as wet condition [5, 6] and it is considered as a limitation in logging tool resolution that has to be looked into. Although low resistivity and low contrast pay can be grouped together, they are actually different. Low resistivity pay is a deep resistivity log curves of approximately 1 to $10 \mathrm{ohm}$. They are also known as the mixing combination of shale content, mineralogy, macro and micro-porosity, and bed thickness. On the other hand, low contrast pay lacks resistivity contrast between pay zones or good area or best formation with oil zones and flanking shale or wet zones. It is a problem when a logging tool passes through a zone that contains fresh water or water in an area of low salinity. As salinity decreases, the conductivity becomes lower and the path for movement of electrical properties becomes weaker and it will attribute to more resistance. Therefore, the resistivity of the water leg should be high enough to record the data for resistivity between pay zone and wet zone, which is difficult to differentiate $[5,7,8]$.

Furthermore, there are also some other factors, for example, the geological aspect factor. They are laminated clean sand with shales, silts or shale sands, clay-couted sand, gloucanite sand, sands with interstitial disperse clay, sand with disseminated pyrite, or other conductive minerals [8]. The geological factor has become a big factor with a combination of bed thickness, grain size, mineralogy, structure of formation, clay distribution, and water salinity. Thus, the conventional logging tool shows poor resolution $[8,9]$ as the formation or the sand is shown as shale due to the lower value of its cut-off zones. With that, the formation is grouped as low contrast and low resistivity reservoir [7].

On finding the resistivity of formation in the reservoir, a resistivity tool is used. There are two types of resistivity package tools, which are Dual Lateral log (DLL) and Induction log. They respond to real rock and all petro-physical analysis to find water saturation, hence, they follow the Archie's Law [12-16]. In fresh water, there is no conductive medium due to the non-ionic solution of the fresh water. So, when resistivity logging is done in fresh water, very high resistivity data are recorded. Therefore, it can be said that the fresh water is poor in conducting electrical current flow. On the other hand, water with saline and rich in mineral is more conductive due to the ionic materials contained in the water and the salinity of the water itself contributes to the conductive liquid. With this principle, the resistivity is conducted to measure the conductive formation in finding the best reservoir with high pay. Basically, most of the sedimentary rocks are very poor in conductive flow [14]. So, most of the conductivity fluid is brine water with ionic salt minerals. 
Hence, the condition of low resistivity with low contrast pay needs to be altered, and one of the ways is by introducing nanoparticles. This is because nanoparticles are materials that are nano in size and the use of nanoparticles has become an interesting method to be incorporated within the research. Besides that, the size of pore and grain in nanoparticles makes it a good injector for formation. The size of pore and grain in a formation is minute, thus, only small particles with good permeability can penetrate the formation [17]. A study conducted by Yu et al. [17] showed that the size of pore and grain is a vital factor and it depends on the coating material for the nanoparticles. In selecting the nanoparticles, it needs to be based on polar and non-polar conditions of the nanoparticles because the nanoparticles need to be hydrophilic so that they can be immiscible into the brine, while oleophilic to be immiscible into the hydrocarbon oil. The main reason for the increasing interest within the industry is due to the numerous advantages that the nanotechnology brings. Known success of implementation of nanoparticles has been documented since its inception. Matteo et al. [18] reported that nanoparticles, when combined with smart fluids, can be deployed as very sensitive downhole sensors for extreme pressure, stress, and temperature. Innovative corrosion-resistant material solution can also be processed with the help of nanotechnology. It extends the lifespan and efficiency of drilling systems and when applied as a corrosion inhibitor for pipelines, nano-layer can act through the creation of permanent molecular layer, thus, can help to reduce $\mathrm{HCl}$ or $\mathrm{H}_{2} \mathrm{~S}$ corrosion.

\section{Materials}

\section{Materials and Methods}

The nanoparticles used were metal oxide nanoparticles with the purity of $99 \%$ and purchased from the US Research Nanomaterials, Inc. USA. The nanoparticles are nickel zinc ferrite oxide $(\mathrm{NiZnFeO})$ and aluminum oxide $\left(\mathrm{Al}_{2} \mathrm{O}_{3}\right)$. Meanwhile, the crude oil sample for the crude oil injection was taken from the Malacca Petronas Refinery plant and the crude oil sample was collected upon receiving it from shipment. The properties of the crude oil are shown in Table 1 below. The sand-pack was fabricated with a cylindrical column prospex glass with 3 points interval distance to measure the resistivity as shown in Table 2 below. The sand-pack fabrication model is also shown in Table 2 below. The resistivity measurements were made using the Keithley Multimeter from the Keithley Instrument, Inc. Cleveland, Ohio USA and recorded using ExceLINX software by the Keithley Instrument. The unit for resistivity will be in ohm.

Table 1. Crude oil Properties

\begin{tabular}{llll}
\hline Crude Oil type & Properties & Value & Unit \\
\hline \multirow{4}{*}{ Tapis } & Density & $0.7665\left(\mathrm{~T}=90{ }^{\circ} \mathrm{C}\right)$ & $\mathrm{g} / \mathrm{cm}^{3}$ \\
& Viscosity & $1.11\left(\mathrm{~T}=90{ }^{\circ} \mathrm{C}\right)$ & $\mathrm{cP}$ \\
& Flash point & 5 & ${ }^{\circ} \mathrm{C}$ \\
& Boiling point & $84-398$ & ${ }^{\circ} \mathrm{C}$ \\
& Chemical & Crude oil $-99 \%$ & Percentage \\
& composition & Benzene $-1 \%$ & \\
\hline
\end{tabular}


Table 2. Sand-pack model dimension and experimental condition

\begin{tabular}{|c|c|c|c|}
\hline Material and Equipment & Descriptions & & \\
\hline \multirow[t]{3}{*}{ Horizontal Sand-pack } & Length & 12 inch & $\begin{array}{l}\text { Channel Resistance distance } \\
\text { taken } \\
\text { - Interval Distance 1: } 3 \text { inch } \\
\text { - Interval Distance 2: } 6 \text { inch } \\
\text { - Interval Distance 3:9 inch } \\
\text { All Interval distance from } \\
\text { inlet. }\end{array}$ \\
\hline & Diameter & 2.5 inch & \\
\hline & Type of sand & $\begin{array}{l}\text { Batik Beach Manjung sand } \\
\text { (40 micrometer in size) }\end{array}$ & \\
\hline
\end{tabular}

\section{Preparation of nanoparticles}

Preparation of nanoparticles with concentration of $1000 \mathrm{ppm}$. The nanoparticles, $\mathrm{NiZnFeO}$ and $\mathrm{Al}_{2} \mathrm{O}_{3}$, were prepared using a $100 \mathrm{~mL}$ beaker. The nanoparticles were weighted before being mixed with $100 \mathrm{~mL}$ of distilled water to produce nano-fluid. In order to make the nanoparticles suspended in the distilled water, the nano-fluid produced needs to control its $\mathrm{pH}$ value of 8 .

Before the nanoparticles were injected into the sand-pack, the sand-pack needs to be pre-prepared first. The cylindrical column that is being fabricated need to be packed with sand. The collected sand needs to be washed with distilled water and dried a few times to make sure that there are no salt contaminations present in the sand. The sand-pack needs to be packed uniformly. After packing, the sand-pack experimental setup was prepared. The setup is shown in Figure 1.

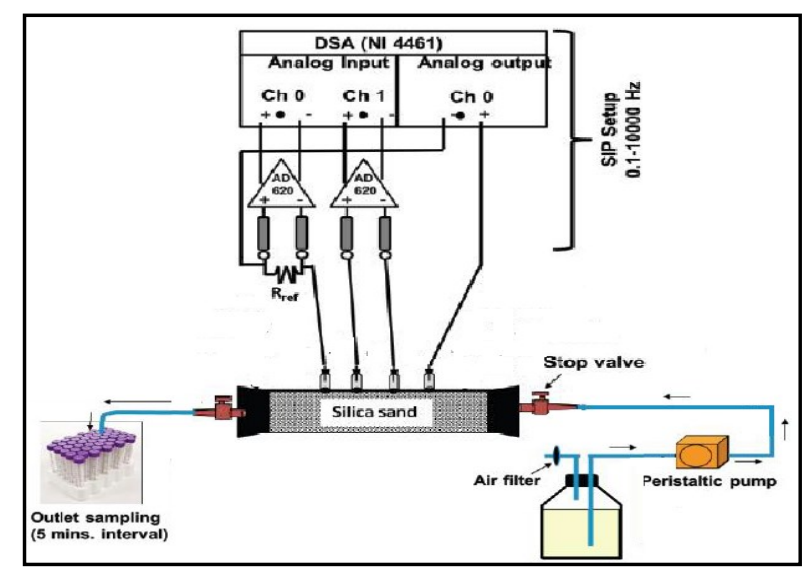

Figure 1. Experimental setup for the sand-pack

Once the process complete, the sand-pack was saturated with $7000 \mathrm{ppm}$ of brine. A fully saturated sand-pack with brine is achieved when there are no more bubbles present in the outlet. After that, the first measurement of resistivity was taken in order to record the resistivity measurement before the injection of nanoparticles.

The injections of nanoparticles were done for $0.25,0.50,0.75$, and 1.00 pore volume of injection. Each injection's volume was $60 \mathrm{~mL}$ and the resistivity measurement was taken after 5 minutes of each injection to make sure that the fluid movement inside the sand-pack was in a static condition without any outlet at the outlet stream. 


\section{Results and Discussion}

The 7000 ppm brine is a typical low salinity water in the Malay Basin [7]. The concentration of nanoparticles is $1000 \mathrm{ppm}$. Properties of the sand-pack are shown in Table 1 and results of the effects of $\mathrm{NiZnFeO}$ and $\mathrm{Al}_{2} \mathrm{O}_{3}$ nanoparticles are given in Table 3 and 4, respectively. As proposed, the resistivity of the brine/water phase showed a reduction from the initial values for $\mathrm{NiZnFeO}$ nanoparticles injection by $14.59,3.94$, and $1.82 \%$ at 3, 6, and 9-inch range, respectively, at the 0.25 pore volume injection of the sand-pack in Table 3 and Figure 2(A). When the experiments were conducted with different pore volumes, the resistivity readings agreed with our expected results. The nanoparticles moved along the interval distance causing a reduction in resistivity and at the pore volume of 1 , the changes increased because the nanoparticles were suspended between the 3 to 9 -inch ranges. It was proven from the measurement of outlet from the test that the amount got it only $0.01 \mathrm{ppm}$ in the outlet collected.

Table 3. Resistivity change in sand pack after injection of $1000 \mathrm{ppm} \mathrm{NiZnFeO}$ nanoparticles (measurement taken every 5 minutes of injection finish)

\begin{tabular}{lcccccccccccccc}
\hline $\begin{array}{l}\text { Pore Volumes } \\
\text { Injected }\end{array}$ & \multicolumn{3}{c}{$\mathbf{0 . 2 5}$} & \multicolumn{1}{c}{$\mathbf{0 . 5 0}$} & \multicolumn{3}{c}{$\mathbf{0 . 7 5}$} & & & $\mathbf{1 . 0 0}$ \\
\hline $\begin{array}{l}\text { Interval distance } \\
\text { from inlet (inch) }\end{array}$ & 3 & 6 & 9 & 3 & 6 & 9 & 3 & 6 & 9 & 3 & 6 & 9 \\
$\begin{array}{l}\% \text { Change in } \\
\text { resistivity of water } \\
\text { zone }\end{array}$ & 14.59 & 3.94 & 1.82 & 12.72 & 3.93 & 3.96 & 12.47 & 3.98 & 1.98 & 2.43 & 10.93 & 14.04 \\
\hline
\end{tabular}

On the other hand, for the $\mathrm{Al}_{2} \mathrm{O}_{3}$ nanoparticles, as shown in Table 4 and Figure 2(b), the initial values of the injected nanoparticles were 5.7, 1.94, and $1.62 \%$ at 3,6, and 9-inch range, respectively, at the 0.25 pore volume injection of the sand-pack. When it went to all of the interval distances, it showed the same patent of decreasing value in terms of percentage difference. It proved that the $\mathrm{Al}_{2} \mathrm{O}_{3}$ had good hydrophilic nanoparticles for the movement of nanoparticles in the brine/water. The difference can be used to differentiate the oil and water zones for log measurements. Within the water zone, the reduction in resistivity indicated that the nanoparticles and traveled along the core, but the heterogeneity in the sand-pack had resulted in uneven resistivity drops.

Table 4. Resistivity change in sand pack after injection of $1000 \mathrm{ppm} \mathrm{Al}_{2} \mathrm{O}_{3}$ nanoparticles (measurement taken every 5 minutes of injection finish)

\begin{tabular}{lccccccccccccc}
\hline Pore Volumes Injected & & $\mathbf{0 . 2 5}$ & \multicolumn{1}{c}{$\mathbf{0 . 5 0}$} & \multicolumn{3}{c}{$\mathbf{0 . 7 5}$} & \multicolumn{3}{c}{$\mathbf{1 . 0 0}$} \\
\hline $\begin{array}{l}\text { Interval distance from } \\
\text { inlet (inch) }\end{array}$ & 3 & 6 & 9 & 3 & 6 & 9 & 3 & 6 & 9 & 3 & 6 & 9 \\
$\begin{array}{l}\text { \% Change in resistivity } \\
\text { of water zone }\end{array}$ & 5.7 & 1.94 & 1.62 & 9.53 & 2.24 & 1.58 & 11.20 & 4.83 & 1.35 & 15.26 & 5.26 & 2.88 \\
\hline
\end{tabular}



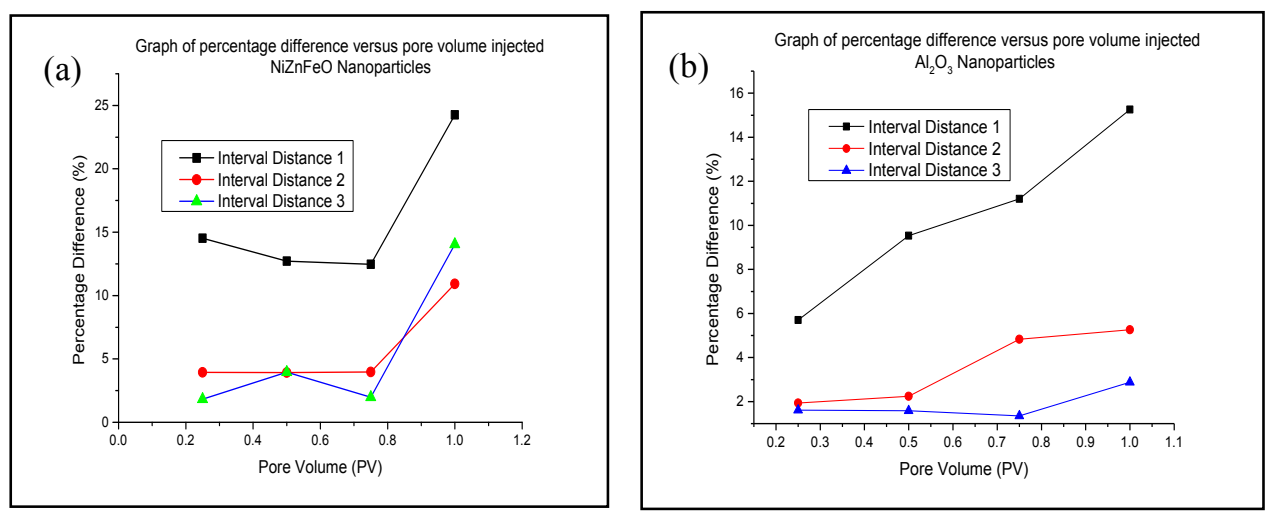

Figure 2. Percentage difference of resistivity value with difference pore volume for a) $\mathrm{NiZnFeO}$ and $b) \mathrm{Al}_{2} \mathrm{O}_{3}$ nanoparticles injection

Both nanoparticles in the experiments showed interests in the water zone. Therefore, the use of both nanoparticles has made it possible to differentiate between the oil and water zones. The results also showed that only a small pore volume was needed to determine the changes. For example, the $\mathrm{NiZnFeO}$ nanoparticles with only 0.5 pore volume of injected nanoparticles can detect the difference in the targeted zone. The same goes for the $\mathrm{Al}_{2} \mathrm{O}_{3}$ nanoparticles. Other than that, a 6-inch traveling distance for the nanoparticles was good enough to show the changes that happened. This condition is suitable for both $\mathrm{NiZnFeO}$ and $\mathrm{Al}_{2} \mathrm{O}_{3}$ nanoparticles.

\section{Conclusion}

It can be concluded that oil zone can be determined using nanoparticles. It is proven by looking at the penetrations done by the $\mathrm{NiZnFeO}$ and $\mathrm{Al}_{2} \mathrm{O}_{3}$ nanoparticles in the sand-pack at 0.25 and 0.50 pore volume. The $\mathrm{NiZnFeO}$ and $\mathrm{Al}_{2} \mathrm{O}_{3}$ nanoparticles were injected and resistivity changes were recorded at the interval distance stated. $\mathrm{NiZnFeO}$ and $\mathrm{Al}_{2} \mathrm{O}_{3}$ nanoparticles showed the same patent for the percentage difference of resistivity at 3 and 6 -inch injections. It can be seen from the percentage difference at 0.25 and 0.50 pore volume of injection. Both nanoparticles favored hydrophilic nanoparticles that went to water zone. Therefore, by having a system with oil water system that is low in contrast during log determination, the nanoparticles will choose the water zone and expose the oil zone. In this case, the oil zone can be determined while making changes for the water zone only. The targeted production zone for oil zone can be clearly stated and determined.

\section{Acknowledgement}

The research was funded by the E-science programme of the Malaysian Ministry of Science, Technology, and Innovation. M. Zulkifli M. Noor's study is made possible by Universiti Malaysia Pahang. We would like to thank Universiti Teknologi PETRONAS for the full access to the excellent laboratory facilities and the staff of the Centre of Research in Enhanced Oil Recovery (COREOR) for providing other support services.

\section{References}

1. Kong, X. and Ohadi, M. (2010). Applications of micro and nano technologies in the oil and gas industry overview of the recent progress. Abu Dhabi International Petroleum Exhibition and Conference, Society of Petroleum Engineers, 1-4 November, Abu Dhabi, UAE, SPE-138241.

2. Riboud, J. and Schuster, N. A. (1971). Well logging techniques, 13-18 June, $8^{\text {th }}$ World Petroleum Congress, WPC-14237.

3. Ellis, D.V. (2007). Well logging for earth scientists. $2^{\text {nd }}$ edition, Dordrecht, The Netherlands: Springer. 17: 692.

4. Fletcher, A. and Davis, J. (2010). How EOR can be transformed by nanotechnology, in SPE Improved Oil Recovery Symposium 2010, Society of Petroleum Engineers. Tulsa, Oklahoma, USA, 1:152 - 167

5. Sneider, R. M. B. and Kulha, J. T. (1993). Low-resistivity, low-contrast productive sands. AAPG Database, 33: $1-4$.

6. Kulha, J. T. (2004). Low Resistivity, Low-Contrast Pays. Houston Geological Society Bulletin, 41(9): 11. 
7. Hamada, G. M., Al-Blehed, M. S., and Al-Awad, M. N. J. (1999). Determining petrophysical properties of low resistivity reservoirs using nuclear magnetic resonance logs. SPE Annual Technical Conference and Exhibition, 3-6 October, Houston, Texas, SPE 56789.

8. Stolper, K. (1994). Identify potential low-resistivity pay using visual rock analysis, Houston Geological Society Bulletin, 37(4): 32.

9. Heavysege, R. G. (2002). Formation evaluation of fresh water shaly sands of the Malay basin, offshore Malaysia. SPWLA 43rd Annual Logging Symposium, Oiso, Japan, 1-14.

10. Amin, N. C. A. R. (2012). Evaluation of low resistivity low contrast reservoir. Dissertation Universiti Teknologi PETRONAS.

11. Boyd, A., Darling, H. and Tabanou, J. (1995). The lowdown on low-resistivity pay. Oilfield Review, 7(3): 4 18.

12. Asquith, G. B. and Gibson, C. R. (1982). Basic well log analysis for geologists. Methods in exploration series. Tulsa, Okla., USA: American Association of Petroleum Geologists. 7: 216.

13. Darling, T. (2005). Well logging and formation evaluation. Gulf drilling guides. Amsterdam; Boston Burlington, MA: Elsevier. Gulf Professional Publication, 9: 326.

14. Crain, E. R. R. (2001). Crain's petrophysical handbook - $3^{\text {rd }}$ Millennium Edition. Online Shareware Petrophysics Training and Reference Manual.

15. Worthington, P. F. (2011). The petrophysics of problematic reservoirs. Journal of Petroleum Technology. 63(12): $88-97$.

16. Archie, G. E. (1942). The electrical resistivity $\log$ as an aid in determining some reservoir characteristics. Society of Petroleum Engineers: Transactions of the AIME, 143(1): $54-62$.

17. Yu, H., Kotsmar, C., Yoon, K. Y., Ingram, D. R., Johnston, K. P., Bryant, S. L. and Huh, C. (2010). Transport and retention of aqueous dispersions of paramagnetic nanoparticles in reservoir rocks. In SPE Improved Oil Recovery Symposium. Society of Petroleum Engineers, Tulsa, Oklahoma, USA, 2: 1027-1047.

18. Matteo, C., Candido, P., Vera, R. and Francesca, V. (2012). Current and future nanotech applications in the oil industry. American Journal of Applied Sciences, 9(6): 784 - 793. 